\title{
Reserves for Increasing the Investment Potential of Hydro-Generating Companies
}

\author{
V.V.Velikorossov, ${ }^{1, *}$, E.V.Genkin ${ }^{1}$, A.K.Zakharov ${ }^{1}$, M.I.Maksimov ${ }^{1}$, V.A.Kozlov ${ }^{1}$, \\ A.K.Khudaibergenov ${ }^{2}$ \\ ${ }^{1}$ Department of Organizational and Administrative Innovations, Plekhanov Russian University of \\ Economics, Moscow, Russia \\ ${ }^{2}$ L.L.C. «Husnutdin Saliev», Nukus, Uzbekistan \\ *Corresponding author
}

Keywords: Energy, Modernization, Structure, Strategy, Investment, Investors, Efficiency, Rating Agencies, Energy Market, Financial and Economic Indicators, Investment Attractiveness

\begin{abstract}
The electricity sector reform created the prerequisites for solving several completely different tasks: creating more attractive conditions for investors, ensuring competition, and increasing the flexibility of investment decisions. The conclusion was made about the significant hydro potential of Russia, as well as significant accumulated experience in the design, construction and operation of hydroelectric power stations, due, among other things, to the construction and operation of large and medium hydroelectric power stations. The effectiveness of the use of a risk-oriented approach to making management decisions, taking into account the risks of production, financial and regulatory nature, including those affecting the value of the company, is shown.
\end{abstract}

\section{Introduction}

The restructuring of the electric power industry has led to the formation of new energy entities, which requires an objective assessment of the effectiveness of their operating activities, as well as investment potential. The foreign practice of rating is difficult to use in relation to Russian energy companies without taking into account the specific features of the functioning of enterprises in a competitive market for electricity and power in Russia.

Currently, the up to date direction of research is the management of the cost of energy companies, taking into account the development of the electricity market. The rating of investment attractiveness of companies in the industry is determined by special rating agencies. Among foreign agencies, the most influential are Moody's, S \& P, Fitch - their analytical studies are widely recognized on all continents.

To determine this rating, the following main functional components of the investment potential of the energy company are used.

1. Technological - the cumulative assessment of physical and moral depreciation of power equipment.

2. Consumer - the aggregate demand for electricity and power in the region.

3. Infrastructure - assessment of the development of network infrastructure. 
4. Innovation - the level of R \& D progress in the power company.

5. Personnel - for the calculation of which data on the number and labor productivity of the power company personnel are used.

6. Financial, expressed in terms of the total amount of tax and other cash receipts to the budget system from an energy company.

\section{Analysis of the Investment Potential of Energy Companies}

Consider the analysis of the investment potential of energy companies on the example of the largest electricity producers in hydroelectric power plants (hereinafter also referred to as HPP).

About 9\% of the world's hydropower reserves are concentrated in the Russian Federation. In terms of hydropower resources, our country ranks second in the world (after the PRC), while outperforming the United States, Brazil and Canada.

Meanwhile, the degree of development of hydro potential in Russia is $20 \%$. For comparison, in Switzerland and France this potential was used by almost $90 \%$, in Canada and China - by more than $60 \%$, in Brazil - by $44 \%$.

The location of water resources which are economically feasible for developing in Russia is uneven: about $80 \%$ of these resources are concentrated in the Eastern parts of the country (Siberia, far East) and only 20\% in the European regions of the country.

But nevertheless, the hydropower may be an acceptable alternative to coal thermal power plants (hereinafter referred to as TPP) in the structure of energy balance of the country. In particular, according to the project of Energy Strategy of Russia until 2035 during 2015-2035 the production of hydropower will increase by 4.1 - 15.6 per cent (depending on the type of scenario - optimistic or conservative), while the volume of production of nuclear energy will increase by $14.7-15.6$ per cent, and the production of electrical energy based on renewable energy - by $87.5-264 \%$.

The capacity of hydropower plants in Russia is 51,2 million $\mathrm{kW}$, which is $20,6 \%$ of the total capacity of power plants in the country. Electricity generation at hydropower plants in the Unified Energy System (UES) of Russia in 2018 amounted to more than 185 billion kWh, the share of hydropower plants in the total electricity generation of UES of Russia power plants was about $20 \%$.

Currently in Russia are functioning 185 hydroelectric power plants, including: 15 hydroelectric power stations with a capacity of more than $1000 \mathrm{MW}, 102$ hydroelectric power stations with a capacity of more than $10 \mathrm{MW}$, two pumped storage power plants (hereinafter also - PSPP) (Zagorsk PSPP and PSPP of the Kuban HPP cascade) and Zelenchukskaya HPP-PSPP with an installed capacity of $140 \mathrm{MW}$. The country's most powerful hydroelectric stations are: SayanoShushenskaya HPP (6.4 GW), Krasnoyarskaya HPP (6 GW), Bratskaya (4.5 GW), Ust-Ilimskaya HPP (3.84 GW) and Boguchanskaya HPP (3 GW) [1].

The operator of the majority of Russian hydropower plants is the RusHydro Group. The company holds a share of about $16 \%$ of the total electrical capacity in Russia and is the largest generating company in the country in terms of installed capacity (taking into account the Holding RAO ES of the East and Boguchanskaya HPP), as well as one of the largest in the world among peers. Group RusHydro generates about 13\% of electricity in Russia (including 61\% of total production HPP), is the largest producer of electric and thermal energy in the Far Eastern Federal district (further - FEFD) (90\% of electricity generation).

The structure of the Group RusHydro includes: 18 hydro-generating branches, 18 generating companies, 4 sales companies, scientific and design institutes, engineering companies, electricity distribution company in the FEFD (JSC "DRSK" - Dal'nevostochnaya Raspredelitel'naya Setevaya Kompaniya - Far Eastern distribution network company). 
Production assets of the Group RusHydro include: 411 power generation facilities with total installed capacity of 39,4 GW in the entire territory of the Russian Federation, the installed thermal capacity (FEFD) - 18,9 thousand Gcal/hour, electric power lines of all voltage classes (FEFD) 104 thousand km Number of staff: 71 thousand people.

The controlling shareholder of PJSC RusHydro is the State represented by the Federal Agency for State Property Management (owns 60,56\% of shares), the remaining shares (39.44\%) belong to minority shareholders, including VTB Bank (PJSC) - 13,55\%; VSMPO-Avisma - 5,96\%; PJSC «Inter RAO» - 1,26\%; Treasury shares - 0,90\%; Private investors - 17,77\% and others.

\section{Analysis of Key Indicators of Production and Financial Activities of the Hydrogenerating Company PJSC RusHydro}

Key results of the RusHydro Group's activities in 2016-2018 are shown in the following tables.

Table 1. Production Results of the RusHydro Group in 2016-2018

\begin{tabular}{|c|c|c|c|c|c|}
\hline Indicator & 2016 & 2017 & Growth, \% & 2018 & Growth, \% \\
\hline Output, billion kWh & 138,8 & 140,3 & $+1,1 \%$ & 144,2 & $+2,8 \%$ \\
\hline HPP & 109,4 & 109,7 & $+0,3 \%$ & 112,5 & $+2,6 \%$ \\
\hline TPP, GeoPP & 29,4 & 30,6 & $+4,0 \%$ & 31,7 & $3,9 \%$ \\
\hline Heat supply, thousand Gcal & 31,5 & 29,6 & $-5,0 \%$ & 29,7 & $-0,9 \%$ \\
\hline
\end{tabular}

In 2017, record levels of power generation were achieved. According to JSC "System Operator of the Unified Energy System of Russia", electricity consumption in Russia as a whole in JanuaryJune 2019 amounted to 541.0 billion kWh (-0.2\% by 2018), production amounted to 551.3 billion kWh $(+0.8 \%$ by 2018$)$.

Table 2. Financial Results of the RusHydro Group in 2016-2018 under Russian Accounting Standards (RAS)

\begin{tabular}{|c|c|c|c|c|c|}
\hline Indicator & 2016 & 2017 & Growth, $\%$ & 2018 & Growth, $\%$ \\
\hline Revenue, billion rubles & 391,3 & 380,9 & $-2,7 \%$ & 400,4 & $+5,1 \%$ \\
\hline EBITDA, billion rubles & 100,3 & 104,2 & $+3,8 \%$ & 109,7 & $+5,3 \%$ \\
\hline Profitability & $25,6 \%$ & $27,4 \%$ & & $27,4 \%$ & \\
\hline Net profit, billion rubles & 39,8 & 24,8 & $-37,7 \%$ & 31,8 & $+28,5 \%$ \\
\hline Profitability & $10,2 \%$ & $6,5 \%$ & & $7,9 \%$ & \\
\hline
\end{tabular}

Table 3. Financial Results of the RusHydro Group for 3 Months of 2019 according to IFRS

\begin{tabular}{|c|c|c|c|}
\hline Indicator & 3 months of the 2018 & 3 months of the 2019 & Growth,\% \\
\hline Revenue, billion rubles & 108,9 & 109,8 & $+0,8 \%$ \\
\hline EBITDA, billion rubles & 31,7 & 29,6 & $-6,8 \%$ \\
\hline Net profit, billion rubles & 23,9 & 16,5 & $-31,0 \%$ \\
\hline
\end{tabular}


Cumulatively for the period 2016-2018 revenue of RusHydro amounted to slightly less than 1,2 trillion rubles, including subsidies, consolidated EBITDA is 314,2 billion rubles., net profit is 96,4 billion RUB. Total amount of dividends paid by RusHydro in the period 2016-2018, is equal to 46,1 billion rubles (more than 60\% of dividends go to the budget of the Russian Federation).

Group RusHydro has reached a high level of financial stability. The amount of net debt decreased to 128,8 billion RUB from 156,0 billion at the end of 2016 due to forward transactions with VTB Bank (PJSC) and the implementation of the plan to reduce costs. The ratio Net debt/EBITDA declined to the quantity of 1.2 .

International credit ratings of RusHydro for the first time in the history of the company upgraded to the sovereign level of the Russian Federation (S\&P "BBB-", Moody's "Ba1", Fitch "BBB-"). Agency ACRA has assigned RusHydro the credit rating of the highest level of reliability "AAA(ru)" on the national scale.

It should be noted that this positive trend in the company's activities is achieved primarily through the use of a cost-based approach to management of the company [2].

One of the main aspects of value management approach is improving the efficiency by optimizing costs. Meanwhile for power industry in general and especially for hydro-power generation the long multi-year investment cycle is typical, indicating the necessity of optimization of activity of the company in the long-term horizon that involves balancing reduction in capital spending in the current period with the future benefits from the implementation of investment projects and development programs.

To maintain this balance, and development of the company RusHydro has carried out techniques and models to assess the economic efficiency of investment projects, as well as consolidated multifactor long-term forecast scenarios of development of the Group included in the Group's development Strategy of RusHydro for the period till 2020 with prospect till 2025.

Key indicators of the cost increase of RusHydro Group include improving the efficiency of operating and investment activities, increasing transparency for market participants and minimise the gap between fundamental and market value.

In its activities, the management of PJSC "RusHydro" also uses a risk-based approach to making managerial decisions with risk-based operational, financial and regulatory nature, including affecting the cost of the company.

The cost-based approach to the management of the company ensures the focus of management processes, systems and solutions to maximize value with mandatory security operation of generating capacities, allowing balanced work to achieve the key strategic objectives of the company.

Table 4. Comparative value of companies by market value multipliers

\begin{tabular}{|c|c|c|c|}
\hline Company & EV / Sales & EV / EBITDA & Price/Earnings \\
\hline RusHydro & $\mathbf{1 , 2}$ & $\mathbf{4 , 2}$ & $\mathbf{6 , 1}$ \\
\hline Inter RAO & 0,3 & 3,2 & 5,2 \\
\hline Unipro & 1,6 & 4,1 & 5,9 \\
\hline Enel Rossiya & 0,9 & 4,0 & 1,7 \\
\hline IrkutskEnergo & 1,0 & 2,8 & 3,5 \\
\hline Rosseti & 1,9 & 2,8 & 5,7 \\
\hline FSK EES & 1,2 & 5,7 & 14,6 \\
\hline $\begin{array}{c}\text { Top 15 global generating } \\
\text { companies (median) }\end{array}$ & 2,1 & 8,5 & \\
\hline
\end{tabular}

It should be understood that the cost-based approach to management is not the result, but constantly evolving process, allowing to effectively implement the key points of growth in the value of the company. For RusHydro Group this means the construction of efficient facilities, increase the 
effectiveness of the program of technical re-equipment and reconstruction, the optimization of the structure of financial investments, further enhancing the effectiveness of the management of the Far Eastern assets of the company and increase their operational efficiency.

The quoted market multipliers show that PJSC RusHydro is highly appreciated compared to Russian generating companies. At the same time, shares of PJSC RusHydro, as well as other Russian companies, are really undervalued compared to the largest foreign peers. This is caused both by a reflection of the market perception of a number of geopolitical and macroeconomic factors, including Western sanctions, the outflow of foreign capital from the Russian stock market, industry regulatory risks, and the fact that the stock market reacts to changes with a time lag, may underestimate or overestimate the impact of particular risks, external events and changes in business, as a result of which the shares of companies may turn out to be both undervalued and overvalued.

In accordance with the ratio of capitalization shown in Table 5 to the cost of $1 \mathrm{~kW}$ of electricity for consumers, RusHydro is comparable to the world's largest counterparts. This suggests an adequate market assessment of the value of RusHydro in the framework of the current cost of electricity in Russia. If the cost of electricity rises to the level of foreign countries, the market value of RusHydro may significantly increase.

Table 5. Comparative value of companies at market value multipliers

\begin{tabular}{|c|c|}
\hline Company & $\begin{array}{c}\text { The ratio of capitalization to the cost of electricity for } \\
\text { consumers }\end{array}$ \\
\hline Iberdrola SA & 1,9 \\
\hline Yangtze Power & 4,8 \\
\hline National Thermal Power Corporation Ltd. & 1,9 \\
\hline Datang International Power Generation & 0,7 \\
\hline EDF & 2,0 \\
\hline NRG & 0,4 \\
\hline RWE AG & 0,5 \\
\hline Huaneng Power International & 1,3 \\
\hline Eletrobras & 0,3 \\
\hline Ruadian Power International & 0,6 \\
\hline Median by world peers & $\mathbf{1 , 3}$ \\
\hline
\end{tabular}

The key issues for the RusHydro Group that require a quick solution are the following activities:

1. Introduction of long-term tariff setting mechanisms in the FEFD

2. Financing of the infrastructure projects by providing targeted budgetary subsidies. This mechanism does not require the issuance of shares and does not have a direct negative impact on the company's capitalization.

4. Construction of new facilities.

5. Development of renewable energy sources (wind, solar, tidal, geothermal power plants).

However, the most significant factor in increasing the competitiveness of renewable energy sources will be the development of economically attractive energy storage technologies, as well as the creation of favorable conditions for their implementation. In the future, progress in these technologies can radically increase the utilization rate of these capacities and make such generation competitive without any additional support.

Russia's high hydro potential is a prerequisite for considering the accumulation of energy, including in the form of hydrogen fuel, as well as its use as a tool for transporting energy. Power storage systems open up fundamentally new opportunities for the development of the power industry and significantly change the modern architecture of the electricity and capacity market by removing the mandatory conditions in terms of the simultaneous generation and consumption of 
electricity, as well as the active introduction of demand management technologies and price arbitrage.

In this regard, currently, many developed and developing countries pursue active policy on the national markets of energy storage systems considering energy storage as one of the key areas of energy development, and actively developing the production of energy storage systems focused on supplying domestic and foreign markets. The main driver of growth is technological progress, leading to reduction in the cost of storage systems to a reasonable level, while ensuring improvement in their performance. Technology development will allow to provide increase of efficiency, decrease of operating costs, and a reduction effect of the increasing depreciation of the storage elements and preserving their ability to accumulate and store the necessary amount of electricity.

According to forecasts of the Center for Strategic Development, the volume of the world market for electric power storage systems in 2025 is estimated at 73.3 billion US dollars, McKinsey Global Institute has included this type of technology among the 12 most significant for the development of world energy. In turn, Navigant Research predicts an increase in the annual input of storage capacity for renewable energy from about $2 \mathrm{GW}$ in 2018 to $24 \mathrm{GW}$ in 2026 - 12 times in eight years, with a proportional increase in annual revenue to \$ 24 billion by 2026 .

For Russia regarding the current situation in the energy industry, the development of systems for energy storage will significantly reduce the problems associated with the classic "bottleneck" of the system of electric power including both UES and isolated zones and a separate power centers, and the formation and maintenance of the production and consumption of electricity.

In addition, active implementation of this direction and the formation of the competence centre will contribute to the fulfillment of tasks on ensuring the technological independence of the energy sector and the development of adequate competencies in all critical to sustainable energy development activities, with increasing level and expanding areas of the global technological competitiveness of the Russian energy sector.

Currently, the only well-developed energy storage technology is hydro-accumulating power plants that convert electricity into the potential energy of water, used at the right time, just like a conventional hydroelectric station. The growing need for energy storage systems has led to the development of scientific research and pilot projects that can dramatically increase the flexibility of decisions and expand the scope of application.

PJSC RusHydro is the only organization in Russia with successful experience in managing energy storage devices on an industrial scale (Zagorsk PSPP with a capacity of 1,200 MW and Zelenchukskaya HPP-PSPP with a capacity of $300 \mathrm{MW})$.

Economic efficiency of the PSPP can also be improved by implementing the following measures:

- giving PSPP the opportunity to serve price a market order, the price of which would include the cost of electric power purchased on the market when operating in pump mode;

- to enact the provisions in the legal and regulatory framework on the absence of PSPPs need to pay for power and transmission services of electrical energy when operating in pump mode;

- the introduction of new paid system services for regulation of the power system due to nonmobile generation facilities for capacity maneuver;

- establishment of tax incentives in reducing/zeroing the rates for property tax, water tax and income tax [3].

Integral effect for the economy in the implementation of these measures include: improving the reliability of power supply and power control in the energy system, the possibility of building nuclear power stations next to the governing PSPP in the limited opportunities of power control in the energy system, but at the same time being a cheap source of electricity, income from job creation, tax and social benefits, building of infrastructure during the construction, the effect of 
tariff reduction for the ultimate consumer, additional investments in the regional economy (savings achieved by generator with the specified support measures).

\section{Conclusion}

In the current economic environment, with a glance to the growing competition, effective functioning of energy companies is possible only in case of development of a comprehensive investment strategy that will improve the company's competitiveness. The purpose of this strategy is to increase the efficiency of the management of energy facilities that will allow: to surmount the crisis and ensuring economic efficiency of power systems, the renewal and modernization of main and auxiliary equipment, creating a single point for the energy management and reducing risks, increasing the reliability of power supply of consumers, attraction of investments in the energy sector.

Regulatory role of the state in the modernization process in the energy sector should manifest itself in greater or lesser extent depending on internal and external economic situation. In crisis and post-crisis conditions, which is currently the Russian Federation the role of the state increases significantly. One of the main factors of sustainable economic development is providing the economy with energy resources at a competitive market price and conditions.

\section{References}

[1] Godovye otchety PAO «RusGidro» za 2016-2018 gody.

[2] Khachaturyan M.V., Klicheva E.V., Velikorossov V.V. (2019) Digital Mechanisms of Development of Possessory Risk Management Systems under New Economic Conditions. Proceedings of the 2019 International Conference on Politics, Economics and Management (ICPEM 2019). Lecture Notes in Economics, Management, and Social Sciences. Clausius Scientific Press, Vol. 5. P. 6-10.

[3] Velikorossov V.V., Genkin V.E., Zaharov A.K. Innovacionnye strategicheskie podhody k strukturnoj modernizacii energetiki $\mathrm{v}$ Rossii // Ekonomika i upravlenie: problemy, resheniya (nauchno-prakticheskij zhurnal). - 2019. - №3, tom 5 (87). S .112-121. 